\title{
PERSEPSI IBU RUMAH TANGGA TERHADAP PERAN GENDER PADA TAYANGAN SINETRON "DUNIA TERBALIK” RCTI
}

\author{
Muhammad Yusuf AR dan Atia Vitalia Aswadany \\ Ilmu Komunikasi Universitas FAJAR \\ Email : jusufar@gmail.com \\ putriatia.aswadany14@gmail.com
}

\begin{abstract}
Television programs present something to be liked. In addition, it must also give a message that brings influence to life in society. The problem of this research is how the housewives' perception of Gamtufkange Urban Village on gender roles in the Reverse World comedy soap opera on RCTI, with the aim of Knowing the perception of Gamtufkange Urban Housewives towards gender roles in the comedy of Reverse World comedy. This research uses a qualitative approach. With primary data sources from informant interviews and secondary data. Data were analyzed using five factors that influence perceptions according to Deddy Mulyana, namely perceptions based on experience, perceptions are selective, perceptions are presumptive, perceptions are evaluative and perceptions are contextual. The theoretical foundation used in this study is the Stimulus-Organism-Response Theory. The results of the study concluded that some housewives disagreed with the role of gender in the soap opera "Reverse World" by reason of their irregularities and cultural and religious norms. Men do not deserve the role that should be done by women in the home. While housewives who agreed to gender roles in the soap opera shows reasoned, a wife working to help their husbands was not taboo and could be accepted. The wife can work to help the family economy, but still must be responsible for taking care of the family.
\end{abstract}

Keywords: Implementation, information disclosure, LAW number 14 year 2008

\section{A. PENDAHULUAN}

Media massa terus mengalami perkembangan sangat pesat. Perkembangan media massa membuat dunia semakin hari semakin dekat, sehingga memberikan sajian informasi dan hiburan kepada khalayak menjadi tak terbatas. Arus informasi dan hiburan itu pun, selalu memberikan dampak positif dan negatif, baik media cetak maupun elektronik.

Media massa cetak dan elektronik merupakan salah satu unsur penting dalam proses komunikasi. Setiap media mempunyai kelebihan dan kekurangan. Kekurangan surat kabar misalnya pada sumber aktualitasnya sebagai media cetak, dimana peristiwa tidak bisa diketahui secara langsung karena harus melewati proses percetakan dahulu sebelum 
bisa dibaca untuk esok harinya. Sedangkan televisi mempunyai kelebihan sebagai media penerangan dan hiburan yang paling digemari masyarakat. Melalui televisi kita dapat melihat suatu peristiwa secara langsung dari tempat kejadian.

Realitas masyarakat saat ini cenderung memilih media televisi sebagai sumber akses informasi dibanding dengan media lainnya. Televisi merupakan media massa terpopuler di kalangan masyarakat, terutama di Indonesia. Menurut Baksin ${ }^{1}$, masyarakat Indonesia termasuk dalam kategori views society, yaitu suatu keadaan dimana kegiatan menonton lebih ditonjolkan dibandingkan lainnya, misalnya kebiasan membaca.

Televisi memiliki unsur-unsur yang menjadi daya tarik dibandingkan dengan media massa lainnya. Unsur audio visual, berupa gambar hidup yang mampu menimbulkan kesan mendalam kepada pemirsanya, menjadikan televisi melebihi daya tarik radio dan film bioskop. Dengan demikian, keberadaan televisi dinilai paling efektif dan diminati dibandingkan media lainnya. Perkembangan teknologinya yang begitu cepat dan jangkauan yang relatif tidak terbatas, menjadikan televisi dapat menarik simpati masyarakat luas. ${ }^{2}$

Perkembangan dunia pertelevisian Indonesia mulai marak sejak pemerintah mengeluarkan izin kehadiran televisi swasta untuk mengudara pada tahun 1989. Salah satunya adalah stasiun televisi yang telah bertahan lama seperti Rajawali Cita Televisi (RCTI). Meskipun awalnya RCTI hanya dapat dinikmati masyarakat melalui antena parabola dan dekoder, namun dengan diizinkannya RCTI sebagai salah satu siaran televisi nasional memberikan warna tersendiri bagi pertelevisian Indonesia, yang selama puluhan tahun hanya menikmati TVRI. RCTI dinikmati secara terbuka mulai 21 Maret 1992 di Bandung. Sebagai salah satu stasiun televisi bersiaran nasional, RCTI telah berhasil menerima banyak penghargaan dan pengakuan di dunia penyiaran. ${ }^{3}$

Program-program acara televisi swasta tidak akan hidup tanpa adanya loyalitas pemirsa. Tiga pilar utama yang harus dimiliki sebuah stasiun penyiaran, yaitu teknik, program, dan pemasaran. Dengan sistem itu diharapkan acara-acara yang hadir dapat

${ }^{1}$ Askurifai Baksin, Jurnalistik Televisi, Teori dan Praktik, (Bandung: Simbiosa Rekatama, 2006), h. 57.

${ }^{2}$ Darwanto, Televisi Sebagai Media Pendidikan, (Yogyakarta: Pustaka Pelajar, 2007), h. 22.

${ }^{3}$ (https://id.m.wikipedia.org/wiki/RCTI). 
digemari penonton. ${ }^{4}$ Sinetron Dunia Terbalik merupakan sinetron RCTI yang membawa pengaruh gender. Diproduksi MNC Pictures yang diperankan Agus Kuncoro, Indra Birowo, Simatupang, Syahnaz Sadiqah, Yafi Tessa, Mieke Amalia, Idrus Madani, Ryana Dea, Lukman Sardi, Felicya Angelista, dan Andi Arsyil Rahman Putra. Dunia Terbalik merupakan program series komedi yang mengangkat cerita tentang para suami yang ditinggalkan istrinya bekerja di luar negeri. Dimulai dari kisah Akum, Aceng, Idoy dan satu musuh bebuyutan Aceng; Dadang. Mereka harus mendidik anak serta mengurus urusan rumah tangga yang biasanya menjadi urusan perempuan. Istrinya harus menafkahi keluarga. Cerita ini mengisahkan masyarakat Jonggol, Bogor, Jawa Barat.

Peneliti memilih tayangan sinetron Dunia Terbalik sebagai objek penelitian, karena sinetron ini merupakan tayangan unggulan RCTI dengan alur cerita yang mudah dipahami dan dapat memikat begitu banyak penonton. Bahkan Dunia Terbalik berada pada rating pertama pada 27 November 2017. ${ }^{5}$ Sinetron Dunia Terbalik mengalahkan sinetron Siapa Takut Jatuh Cinta dan Anak Langit yang tayang di SCTV, Jodoh Wasiat Bapak yang tayang di ANTV, dan lain-lain.

Sinetron Dunia Terbalik banyak meraih prestasi. Penghargan dari Indonesian Televison Awards 2017 kategori program prime time drama terpopuler, Panasonic Gobel Awards 2017, kategori drama seri terfavorit, Anugerah Komisi Penyiaran Indonesia 2017, kategori program drama seri, Festival Film Bandung 2017 kategori serial televisi terpuji, Anugerah Syiar Ramadhan 2017 kategori program sinetron Ramadan terbaik, Silet Awards 2017 kategori sinetron "Tersilet".

Sementara itu, salah satu alasan mengapa memilih masyarakat Tidore sebagai objek penelitian atas popularitas sintron Dunia Terbalik, karena sebagai kerajaan yang bercorak Islam, masyarakat Tidore memiliki sejarah panjang terkait penerapan syariat Islam dalam kehidupan sehari-hari. Hal itu dapat dilihat pada Sultan Nuku dari Tidore dengan De Mesquita dari Portugal yang melakukan perdamaian dengan mengangkat

\footnotetext{
${ }^{4}$ Morissan, Manajemen Media Penyiaran, (Jakarta: Kencana Prenadamedia Group, 2008), h. 133.

${ }^{5}$ Lihat, www.duniatv.net. (Akses, 29 April 2018).
} 
sumpah di bawah kitab suci Al-Quran. Selain itu sebesar 91,93 persen masyarakat Tidore beragama Islam, sisanya Kristen, dan Hindu. ${ }^{6}$

Bagi masyarakat Tidore, yang mayoritas Muslim, suami memegang peran dominan sebagai pemberi nafkah keluarga, isteri, dan anak. Masyarakat Tidore, seorang suami harus berkerja keras menafkahi isteri dan anaknya. Bagi mereka, istri masih dapat bekerja tanpa meninggalkan kewajiban utama untuk merawat anak dan suami. Dominasi istri dalam bekerja akan menimbulkan citra negatif pada suami. Fakta ini sangat bertolak belakang dengan pesan cerita sinetron Dunia Terbalik.

\section{B. TINJAUAN PUSTAKA}

\section{Definisi Persepsi}

Persepsi adalah proses kognitif yang dialami oleh setiap orang dalam memahami informasi tentang lingkungannya, baik melalui penglihatan, pendengaran, penghayatan, perasaan, dan penciuman. Memahami bahwa persepsi merupakan penafsiran yang unik terhadap situasi dan bukan pencatatan yang benar terhadap situasi, merupakan kunci pemahaman atas persepsi. Faktor-faktor fungsional, termasuk kesiapan mental dan susasana emosi yang memengaruhi psikologi seseorang serta latar belakang budaya, sangat menentukan persepsi sesorang. ${ }^{7}$ Sementara menurut Ridwan (2016), persepsi adalah proses mengungkap arti objek sosial dan peristiwa yang dialami dalam lingkungan kita. Oleh karena itu, setiap orang memiliki gambaran yang berbeda mengenai realitas di sekelilingnya. ${ }^{8}$

\section{Kategori Persepsi}

Menurut Mulyana ${ }^{9}$ kategori persepsi pada manusia terdiri atas dua bagian, yaitu persepsi terhadap objek (lingkungan fisik) dan persepsi terhadap manusia (sosial).

\section{${ }^{6}$ (http://id.m.wikipedia.org/wiki/Kesul-tanan Tidore).}

7Jalalauddin Rahmat, Psikologi Komunikasi, (Bandung: Remaja Rosdakarya, 2000), h. 40.

${ }^{8}$ Aang Ridwan, Komunikasi Antar Budaya: Mengubah Persepsi dan Sikap dalam Meningkatakan Kreativitas Manusia, (Bogor: CV Pustaka Setia, 2016), h. 89.

${ }^{9}$ Deddy Mulyana, Ilmu Komunikasi, Suatu Pengantar (Bandung: PT Remaja Rosdakarya, 2007), h. 184. 
Kedua jenis persepsi tersebut memiliki beberapa perbedaan. Pertama, persepsi lingkungan fisik merupakan proses penafsiran terhadap objek-objek tidak bernyawa yang ada di sekitar lingkungan kita. Terkadang saat mempersepsi lingkungan fisik, kita melakukan kekeliruan, karena indera terkadang menipu itulah yang disebut ilusi. Persepsi terhadap objek ini dipengaruhi beberapa faktor, yaitu latar belakang pengalaman, budaya, psikologis, nilai, keyakinan, harapan, dan yang terakhir adalah kondisi faktual alat indera.

Kedua, persepsi sosial adalah proses menangkap arti objek-objek sosial dan kejadian yang dialami dalam lingkungan manusia. Oleh karena itu manusia bersifat emosional, sehingga penilaian terhadap orang akan mengandung risiko.

\section{Program Televisi}

Kata program berasal dari bahasa Inggris programme atau program yang berarti acara atau rencana. Undang-undang penyiaran Indonesia tidak menggunakan kata program untuk acara, tetapi menggunakan istilah "siaran” yang didefinisikan sebagai pesan atau rangkaian pesan yang disajikan dalam berbagai bentuk. Program siaran itulah yang menarik audiens untuk menonton atau mendengar media elektronik tv atau radio. Atau dengan kata lain, program siaran inilah yang menjadi produk yang dijual kepada pihak lain, dalam hal ini audiens dan pemasang iklan.

Bagian program yang bagus, terdiri atas orang-orang yang telah belajar untuk mengukur selera atau cita rasa publik melalui penelitian untuk mengetahui kebiasaan orang menonton televisi atau mendengarkan siaran radio. Seorang perencana acara yang baik akan selalu mempertimbangkan bagaimana agar acara itu bisa digemari.

Stasiun televisi setiap harinya menyajikan berbagai jenis program yang jumlahnya sangat banyak dan jenisnya sangat beragam. Pada dasarnya apa saja bisa dijadikan program untuk ditayangkan di televisi selama program itu menarik dan disukai audiens, plus tidak bertentangan dengan asas kesusilaan, hukum, dan peraturan yang berlaku.

\section{Sinetron}

Sinema elektronik atau lebih populer disebut sinetron adalah sandiwara yang disiarkan oleh stasiun televisi. Sinetron pada umumnya bercerita mengenai kehidupan sehari-hari yang diwarnai dengan konflik, seperti halnya drama maupun sandiwara. 
Sinetron diawali perkenalan tokoh-tokoh yang memiliki karakter masing-masing. Berbagai karakter yang berbeda-beda menimbulkan konflik yang semakin lama semakin besar sehingga pada titik klimaks. ${ }^{10}$

Sinetron sebagai suatu media komunikasi merupakan kombinasi antara usaha penyampaian pesan melalui gambar yang bergerak. Pemanfaatan teknologi kamera gambar, dan suara.Unsur-unsur tersebut dilatarbelakangi oleh suatu cerita yang mengandung suatu pesan yang ingin disampaikan sutradara kepada khalayak sinetron.

\section{Peran Gender}

Menurut teori nurture adanya perbedaan perempuan dan laki-laki pada hakekatnya adalah bentukan masyarakat melalui konstruksi sosial budaya, sehingga menghasilkan peran dan tugas yang berbeda. Perbedaan itu menyebabkan perempuan selalu tertinggal dan terabaikan peran dan kontribusinya dalam hidup berkeluarga, bermasyarakat, berbangsa dan bernegara. Konstruksi sosial menempatkan perempuan dan laki-laki dalam perbedaan kelas. Laki-laki diidentikkan dengan kelas borjuis, dan perempuan sebagai proletar.

\section{Teori Stimulus Organism Respons (SOR)}

Teori S-O-R singkatan dari Stimulus-Organism-Respon. Asumsi dasa dari model ini adalah media massa menimbulkan efek yang terarah, segera dan langsung terhadap komunikan. Model ini menunjukan bahwa komunikasi adalah proses aksi-reaksi. Atau dengan kata lain, kata-kata verbal, isyarat non verbal, simbol-simbol tertentu akan merangsang orang lain untuk memberikan respon dengan cara tertentu. Pola S-O-R ini dapat berlangsung secara positif atau negatif.

Menurut stimulus respon ini, efek yang ditimbulkan adalah reaksi khusus terhadap stimulus, sehingga seseorang dapat mengharapkan dan memperkirakan kesesuaian antara pesan dan reaksi komunikan. Unsur-unsur dari model ini adalah: (1) pesan (stimulus); (2) komunikan (organism): Perhatian, pengertian, penerimaan; dan (3) efek (respon) perubahan sikap. Proses dari perubahan sikap adalah serupa dengan proses belajar. Dalam mempelajari sikap ada tiga variabel yang penting menunjang proses

\footnotetext{
${ }^{10}$ Onong Uchjana Effendy, Ilmu Komunikasi, Teori dan Praktik, PT Remaja Rosdakarya: Bandung (2008).
} 
belajar tersebut yaitu: perhatian, pengertian, penerimaan. Sikap yang dimaksud disini adalah kecenderungan bertindak, berpikir, berpersepsi dan merasa dalam menghadapi objek, ide, situasi atau nilai. Sikap bukanlah perilaku, tetapi lebih merupakan kecenderungan untuk berprilaku dengan cara tertentu terhadap objek sikap, dengan demikian pada kenyataan tidak ada istilah sikap yang berdiri sendiri. Sikap juga bukan sekadar rekaman masa lalu, tetapi juga menentukan apakah seseorang harus setuju atau tidak terhadap sesuatu, menentukan apa yang disukai dan diharapakan.

Sikap mengandung aspek evaluatif. Artinya mengandung nilai menyenangkan atau tidak menyenangkan terhadap objek, orang, situasi, dan mungkin aspek aspekaspek lain dunia, termasuk ide bstrak dan kebijaksanaan sosial. Dengan demikian ahli psikologi sosial biasanya memandang sikap sebagai gabungan dari komponen kognitif, komponen afektif, dan komponen perilaku.

Pengukuran persepsi dalam penelitian ini menggunakan indikator menurut Mulyana $^{11}$, sebagai berikut:

1) Persepsi berdasarkan pengalaman. Persepsi manusia terhadap seseorang, objek, atau kejadian dan reaksi mereka terhadap hal-hal itu berdasarkan pengalaman masa lalu mereka berkaitan dengan orang, objek, atau kejadian serupa, termasuk misalnya cara kita bekerja dan menilai pekerjaan apa yang baik bagi kita.

2) Persepsi bersifat selektif. Dipengaruhi faktor-faktor internal yakni faktor biologis (lapar,haus, dan sebagainya) faktor fisiologis (tinggi, pendek, gemuk, kurus, sehat, sakit, lelah, penglihatan, atau pendengaran kurang sempurna,cacat tubuh, dan sebagainya) dan faktor-faktor sosial budaya seperti gender, agama, tingkat pedidikan, pekerjaan, penghasilan, peranan, status soasia, pengalaman masa lalu, kebiasaan dan bahkan faktor-faktor psikiologis seperti kemauan, keinginan, motivasi, pengharapan, kemarahan, kesedihan, dan sebagainya.

3) Persepsi bersifat dugaan. Dugaan diperlukan untuk membuat kesimpulan berdasarkan informasi yang tidak lengkap lewat penginderaan. Persepsi bersifat

${ }^{11}$ Deddy Mulyana, Ilmu Komunikasi, Suatu Pengantar, (Bandung: PT Remaja Rosdakarya, 2016), h. 191-207. 
evaluatif. Tidak seorang pun mempersepsi suatu objek tanpa mempersepsi seberapa "baik" atau "buruk" objek tersebut.

4) Persepsi bersifat evaluatif. Bahwa realitas tidak dapat dipersepsi tanpa melalui suatu proses unik dan alasan sangat pribadi untuk bertindak dalam suatu hubungan sosial. Tidak seorang pun mempersepsi suatu objek tanpa mempersepsi seberapa "baik" atau "buruk" objek tersebut.

5) Persepsi bersifat kontekstual. Rangsangan dari luar harus diorganisasikan. Dari semua pengaruh paling kuat, konteks adalah salah satu pengaruh paling kuat. Ketika kita melihat seseorang, suatu objek atau suatu kejadian, konteks rangsangan sangat memengaruhi struktur kognitif, pengharapan dan oleh karenanya juga persepsi kita.

\section{PEMBAHASAN}

\section{Analisis Persepsi Ibu Rumah Tangga terhadap Peran Gender pada Sinetron Dunia Terbalik}

Persepsi sosial dalam hal ini adalah bagaimana narasumber memaknai peran gender yang terdapat pada sinetron Dunia Terbalik, hubungannya dengan budaya Tidore sesuai dengan kelompok faktor persepsi sosial yang dikemukakan Mulyana.

\section{Persepsi Berdasarkan Pengalaman}

Persepsi berdasarkan pengalaman adalah bagaimana tindakan menyusun, mengenali, dan menafsirkan informasi sensoris sinetron Dunia Terbalik berdasarkan pengalaman ibu-ibu rumah tangga sesuai usia pernikahan. Berdasarkan pengalaman menikah lebih dari 20 tahun (usia pernikahan tua), peran gender dalam sinetron Dunia Terbalik kurang disetujui oleh seluruh narasumber dengan alasan ketidakwajaran dan norma budaya serta agama yang mengikat.

Menurut mereka, laki-laki tidak pantas melakukan peran yang seharusnya dikerjakan oleh wanita dalam rumah tangga seperti mencuci, memasak, membersihkan rumah, mengurus anak secara dominan dan lain sebagainya. Bahkan bagi mereka karakter laki-laki yang sangat tergantung kepada wanita sama sekali kurang pantas ditunjukkan dalam budaya Tidore. Dengan alasan apapun, mereka tidak sepakat dengan peran gender yang dimainkan dalam sinetron Dunia Terbalik. Seperti yang dikemukan oleh Salma: 
"Saya tidak setuju dengan peran gender yang ada di dalam tayangan sinetron Dunia Terbalik. Sangat bertolak belakang dengan adat dan budaya Tidore. Seharusnya peran seorang suami itu untuk menafkahi anak dan istrinya, bukan istri yang menafkahi suami dan anak. Apalagi meninggalkan sampai bertahuntahun. Itu semua demi menjaga harga diri dan martabatnya seorang suami.",12

Umumnya laki-laki dianggap sebagai manusia gagah perkasa, tidak emosional dan senantiasa rasional. Punya kemampuan memimpin, berwibawa dan menggemari aktivitas menantang. Dalam hal ini, bekerja merupakan tanggung jawab laki-laki yang memiliki sifat-sifat tersebut. Sementara perempuan justru sebaliknya. Sifatnya lemah lembut, senantiasa menarik dan anggun menawan. Pintar memasak dan mengemas rumah, rasa atau emosi lebih menonjol. Efektif dalam membantu tapi kurang berupaya memimpin dan lebih meminati aktivitas domestik. Tanggapan umum melihat bahwa dalam sebuah rumah tangga, sebagai suami dan ayah adalah pemimpin sementara isteri dan ibu berperan sebagai pembantu dan pengikut yang setia. ${ }^{13}$

Berdasarkan hasil wawancara narasumber dengan pengalaman pernikahan kurang dari 10 tahun (usia pernikahan muda), cenderung lebih terbuka dan tidak terlalu kaku mengenai perubahan peran dalam rumah tangga. Bagi mereka istri bekerja membantu suami, bukan hal tabu dan dapat diterima. Namun, dalam konteks ini mereka rata-rata kurang sepakat dengan fungsi dominan yang tertukar, dimana secara penuh tanggung jawab suami diperankan istri, begitupula sebaliknya. Menurut mereka, istri boleh bekerja membantu perekonomian keluarga, tetapi tetap harus bertanggung jawab mengurus keluarga (suami dan anak). Istri bekerja di luar bukan untuk mencari nafkah utama. Begitu pula suami membantu pekerjaan isteri di rumah hanya untuk meringankan beban isteri saja. Semua dilakukan atas dasar saling membantu dan dengan konsensus bersama. Menurut mereka dengan adanya kerjasama dan saling membantu, maka akan menciptakan keharmonisan dan keseimbangan dalam rumah tangga.

Namun demikian, mereka kurang setuju dengan alur cerita sinetron Dunia Terbalik, dimana isteri harus meninggalkan suami jauh dan dalam waktu yang sangat lama sebagai TKW. Seperti pernyataan Rahmidhany:

\footnotetext{
${ }^{12}$ Salma, Wawancara, 25 Juni 2018.

${ }^{13}$ Aminuddin Lubis, Konsep dan Isu Gender dalam Islam.
} 
"Walau bisa isteri membantu suami bekerja, tapi saya tidak setuju dengan alur cerita di Dunia Terbalik, yang mana isteri berpisah dengan suami sangat lama. Pergi jauh menjadi TKW. Tapi, dari segi komedi masih bolehlah, sangat menghibur."14

Mereka tidak mempertentangkan peran antara kaum perempuan dan laki-laki, karena keduanya harus bekerjasama dalam kemitraan dan keharmonisan dalam kehidupan keluarga.

\section{Persepsi Bersifat Selektif}

Persepsi bersifat selektif dikelompokkan menjadi dua, yaitu tingkat pendidikan dan pekerjaan. Berdasarkan tingkat pendidikan, narasumber dibagi menjadi yang berpendidikan tinggi (sarjana) dan tidak berpendidikan tinggi (tingkat SMA) sedangkan menurut pekerjaan dikelompokkan menjadi pekerja dan non pekerja.

Relevansi dari pemikiran dan persepsi terhadap pendidikan dan pekerjaan sangat erat. Mereka dengan latar belakang pendidikan rendah, cenderung merupakan ibu rumah tangga yang tidak bekerja. Pemikiran mereka terhadap peran gender lebih tertutup (kaku). Hal ini dapat dilihat dari petikan wawancara dari beberapa responden, misalnya Nuryati Tumcala:

"Dunia Terbalik ceritanya lucu, tapi bertolak belakang dengan tong pe budaya. Tidak masuk akal isteri kerja sampe tinggalkan suami. Baru suami cuma tau tunggu kiriman uang dari isteri. Aneh kalo suami yang urus rumah tangga dan kerjanya bagosip.",15

Konstruksi sosial menempatkan perempuan dan laki-laki dalam perbedaan kelas. Namun demikian, ada juga masyarakat yang fleksibel dalam memperbolehkan laki-laki melakukan pekerjaan perempuan dan sebaliknya. Sebagian besar mereka adalah dari kelas pendidikan tinggi (sarjana). Bagi mereka, pembagian peran itu merupakan dinamika dan harmonisasi dalam keluarga dan berumah tangga. $\mathrm{Hj}$. Zulaiha termasuk golongan ini:

"Kalo menurut saya sah-sah saja, tidak terlalu paksa laki bekerja juga. Karena laki juga mungkin yang tau diri, karena belum ada kesibukan yah bantu isteri.

\footnotetext{
${ }^{14}$ Rahmidhany, Wawancara, 19 Juni 2018.

${ }^{15}$ Nuryati Tumcala, Wawancara, 20 Juni 2018.
} 
Dari segi agama juga tra masalah, karena Rasulullah SAW juga mengajarkan demikan. Budaya tidore harusnya tra terlalu mengikat."16

Harmonisasi dalam rumah tangga menurut golongan ini dapat terbentuk salah satunya dengan kerjasama dan saling menghargai.

\section{Persepsi Berdasarkan Dugaan}

Dalam penelitian ini, persepsi berdasarkan dugaan dimaknai dengan mewawancarai ibu rumah tangga yang belum menonton sinetron Dunia Terbalik. Informasi yang akan diterima berasal dari mereka yang hanya mengetahui judul dan sinopsis singkat dari sinetron Dunia Terbalik, sehingga banyak dugaan yang menghasilkan persepsi terhadap sinetron Dunia Terbalik dari informan tersebut.

Hasil wawancara beberapa ibu rumah tangga yang tidak menonton keseluruhan sinetron, terdapat beragam respon dan persepsi terutama terkait dengan peran gender dari sudut pandang budaya Tidore. Berikut kutipan hasil wawancara bersama Desiyanti:

“... perempuan dan laki-laki dalam rumah tangga, tentunya sebelum tong nikah harus ada kesepakatan. Tapi memang walau bagaimanapun laki-laki jadi tulang punggung karena dia pemimpin rumah tangga. Perempuan boleh saja membantu tapi ada batasan."17

Selain itu, suami wajib melindungi istri dan memberi segala keperluan hidup rumah tangga dengan kemampuannya. Sementara seorang istri bertugas mengatur rumah tangga sebaik-baiknya. Dengan pembagian peran tersebut, berarti peran perempuan yang resmi diakui adalah peran domestik yaitu peran mengatur urusan rumah tangga seperti membersihkan rumah, mencuci baju, memasak, merawat anak dan berkewajiban untuk melayani suami. Berikut adalah hasil petikan wawancara dengan Ida Nur Albar:

"Menurut saya, laki-laki adalah pemimpin. Kalo namanya pemimpin dia yang bertanggung jawab terhadap apa-apa dalam rumah tangga, termasuk cari nafkah.... Kalo sudah laki-laki bertanggung jawab, berlaku baik, memenuhi kebutuhan istri dan anak-anak, istri ya harus nurut. Melakukan kewajiban sebagai istri dengan baik." 18

Selain itu, terdapat peran yang masih dianggap sesuai dengan kondisi sosial budaya Tidore yaitu peran Koswara (suami Kokom). Dalam sinetron tersebut, Koswara tidak sependapat dengan kebiasaan lingkungan desa Cikadu yang membolehkan istri

\footnotetext{
${ }^{16} \mathrm{Hj}$. Zulaiha, Wawancara, 21 Juni 2018.

${ }^{17}$ Desiyanti, Wawancara, 21 Juni 2018.

${ }^{18}$ Ida Nur Albar, Wawancara, 20 Juni 2018.
} 
bekerja menjadi TKW. Namun demikian, Kokom (istri Koswara) yang ingin memiliki penghasilan besar tidak sepakat dengan Koswara. Kondisi ini mengakibatkan terjadinya konflik yang berkepanjangan dalam rumah tangga mereka. Responden menduga kondisi tersebut disebabkan istri yang tidak bersyukur dan iri hati. Sebagaimana petikan wawancara dengan Desiyanti berikut:

"Menurut saya wajar sih Kokom tra terima dilarang suami bekerja, karena dia tidak bersyukur dan merasa iri barangkali ee liat keluarga lain banyak uang, karena jadi TKW itu pasti uang banyak. Tapi saya senang suaminya. Dia tegas. Harga diri masih tinggi itu, hahaha." 19

Dugaan yang memengaruhi persepsi ibu-ibu rumah tangga yang hanya menonton beberapa segmen tersebut secara garis besar mengindikasi bahwa stimulus sebagaimana teori SOR terhadap sebagian tayangan Dunia Terbalik memengaruhi komunikan karena adanya perhatian. Perhatian tersebut kemudian membentuk pemahaman yang akhirnya menciptakan sebuah persepsi.

Secara garis besar, fungsi yang dimiliki oleh media penyiaran televisi sama halnya dengan fungsi yang dimiliki oleh media massa lainya. Fungsi media tersebut antara lain, fungsi menyebarkan informasi, fungsi mengedukasi, fungsi menghibur dan fungsi memengaruhi. Hal ini berkaitan dengan teori S-O-R (Stimulus-OrganismRespon) yang mengasumsikan bahwa media massa menimbulkan efek yang terarah, segera dan langsung terhadap komunikan. Teori ini menunjukan bahwa komunikasi adalah proses aksi-reaksi, dimana terdapat respon yang memengaruhi persepsi seseorang baik positif maupun negatif.

Selain itu, beberapa dialog dalam sinetron Dunia Terbalik cukup memengaruhi penonton, khususnya ibu-ibu muda yang acapkali menirukan gaya bahasa yang digunakan pemain. Perspesi sosial yang terkait dengan budaya dalam sinetron Dunia Terbalik menggambarkan, sinetron ini seperti umumnya tayangan lain di televisi, mengindikasikan adanya kecendrungan tayangan yang berorietasi profit sehingga memungkinkan terdapat upaya transformasi nilai-nilai budaya asing yaitu budaya matriarki dimana tugas suami diperankan oleh istri dan tugas istri diperankan oleh suami.

\footnotetext{
${ }^{19}$ Desiyanti, Wawancara, 21 Juni 2018
} 
Berdasarkan temuan pada seluruh faktor persepsi pada aspek sosial yang telah dilakukan sebelumnya, terdapat tiga pandangan persepsi. Persepsi pertama masuk kategori kaum nuturistik yang menganggap bahwa adanya perbedaan perempuan dan laki-laki adalah hasil konstruksi sosial budaya sehingga menghasilkan peran dan tugas yang berbeda. Perbedaan itu membuat perempuan hanya mengurusi masalah domestik rumah tangga tanpa diperkenankan untuk bekerja di luar. Persepsi ini bertolak belakang dengan alur cerita sinetron Dunia Terbalik. Responden dengan pandangan nuturistik ini berasal dari kalangan ibu-ibu dengan pengalaman lebih dari 10 tahun serta dengan tingkat pendidikan rendah dan mereka yang hanya bekerja sebagai ibu rumah tangga (tidak bekerja di luar rumah).

Persepsi kedua tergolong kelompok nature yang memandang perbedaan antara laki-laki dan perempuan sebagai kodrat, sehingga harus diterima. Perbedaan biologis ini memberikan indikasi dan dan implikasi bahwa diantara kedua jenis kelamin tersebut memiliki peran dan tugas berbeda. Ada peran yang dapat dipertukarkan, namun ada yang tidak bisa. Dalam kaitannya dengan pembagian tugas di rumah tangga, masih memungkinkan untuk istri bekerja, tetapi hanya untuk membantu suami. Tugas utama istri adalah melayani suami, anak, dan mengurus rumah tangga. Sehingga terdapat beberapa jenis pekerjaan yang masih memungkinkan dikerjakan istri dalam rangka membantu perekonomian keluarga terutama pada pekerjaan yang tidak menyita waktu lama di luar rumah.

Persepsi ketiga adalah responden dengan pendekatan keseimbangan (equilibrium) yang menekankan pada konsep kemitraan dan keharmonisan dalam hubungan antara perempuan dan laki-laki. Pandangan ini tidak mempertentangkan antara peran laki-laki dan perempuan, karena keduanya harus bekerja sama dalam kemitraan dan keharmonisan dalam kehidupan bekeluarga hingga bernegara. Hubungan diantara kedua elemen tersebut bukan saling bertentangan tetapi hubungan komplementer guna saling melengkapi satu sama lain. Persepsi ini dapat menerima sinetron Dunia Terbalik sebagai budaya yang bisa diterapkan di Tidore, namun dengan pengecualian. Misalnya, karena suami sakit, lumpuh dan kondisi lain yang tidak memungkinkan suami untuk bekerja. Selain itu, kelompok ini memiliki persepsi bahwa istri dapat bekerja di luar rumah untuk membantu perekonomian keluarga, begitu juga 
suami yang dapat melakukan pekerja rumah tangga yang menjadi tanggung jawab istri. Kelompok dari persepsi ini adalah ibu-ibu rumah tangga muda dengan pengalaman menikah kurang dari 10 tahun dan dengan kategori tingkat pendidikan tinggi.

\section{KESIMPULAN}

Persepsi berdasarkan pengalaman, dengan kategori usia pernikahan lebih dari 10 tahun (usia pernikahan tua), peran gender dalam sinetron Dunia Terbalik kurang disetujui oleh informan dengan alasan ketidakwajaran dan norma budaya serta agama yang ada. Laki-laki tidak pantas melakukan peran yang seharusnya dikerjakan oleh wanita dalam rumah. Beda halnya dengan ketegori usia pernikahan kurang dari 10 tahun (usia pernikahan muda). Bagi mereka istri bekerja membantu suami bukan hal yang tabu dan dapat diterima. Istri boleh bekerja untuk membantu perekonomian keluarga, tetapi tetap harus bertanggung jawab mengurus keluarga.

Persepsi bersifat selektif dengan kategori ibu rumah tangga pekerja pegawai negeri sipil dan ibu rumah tangga berpendidikan tinggi (sarjana) menyetujui dengan peran gender pada tayangan sinetron Dunia Terbalik. Pembagian peran itu merupakan dinamika dan harmonisasi dalam keluarga dan berumah tangga untuk kebutuhan hidup. Berbeda halnya dengan kategori ibu rumah tangga tidak bekerja dan ibu rumah tangga non-pendidikan tinggi (tidak sarjana), tidak menyetujui adanya pergantian peran gender pada tayangan sinetron Dunia Terbalik. Menurut mereka kedudukan laki-laki sebagai seorang suami terkait perannya dalam rumah tangga, yaitu pencari nafkah (pekerja) dan istri tinggal di rumah mengurus anak dan pekerjaan domestik lainnya.

Persepsi berdasarkan Dugaan. Informan dengan kategori ini tidak menyetuji peran gender yang ada pada tayangan sinetron Dunia Terbalik. Suami wajib melindungi istri dan memberi segala keperluan hidup rumah tangga dengan kemampuannya. Sementara seorang istri bertugas mengatur rumah tangga sebaik-baiknya. Peran perempuan yang resmi diakui adalah peran domestik yaitu peran mengatur urusan rumah tangga seperti membersihkan rumah, mencuci baju, memasak, merawat anak dan berkewajiban untuk melayani suami. Namun demikian, pada prinsipnya kondisi sosial tersebut tidak menyebabkan konflik rumah tangga karena diduga sudah ada kesepakatan dan komitmen bersama. 


\section{DAFTAR PUSTAKA}

\section{Buku-Buku}

Baksin, Askurifai. 2006. Jurnalistik Televisi, Teori dan Praktik. (Bandung: Simbiosa Rekatama).

Bungin, M. Burhan. 2008. Penelitian Kualitatif. (Jakarta: Kencana Pernada Media Group).

Cangara, Hafied. 2007. Pengantar Ilmu Komunikasi, (Jakarta: PT Rajawaigrafindo Persada).

Darwanto. 2007. Televisi Sebagai Media Pendidikan, (Yogyakarta: Pustaka Pelajar).

Effendy, Onong Uchjana. 2005. Ilmu Komunikasi Teori dan Praktik. (Bandung: PT Remaja

Rosdakarya).

. 2008. Dinamika Komunikasi. (Bandung: PT Remaja Rodakarya).

Latief, Rusman dan Yusiatie Utud. 2015. Siaran Televisi Non-Drama: Kreatif, Produktif, Publik Relations, dan Iklan. (Jakarta: Prenadamedia Group).

Moleong, Lexy. J. (2010). Metodologi Penelitian Kualitatif, (Bandung: Remaja

Rosdakarya).

Morissan. 2008. Manajemen Media Penyiaran, (Jakarta: Kencana Prenadamedia

Group).

Mulyana, Deddy. 2007. Ilmu Komunikasi, (Bandung: PT Remaja Rosdakarya Offset).

Rahmat, Jalaluddin. 2000. Psikologi Komunikasi, (Bandung: Remaja Rosdakarya).

Ridwan, Aang. 2016. Komunikasi Antar Budaya: Mengubah Persepsi dan Sikap dalam Meningkatakan Kreativitas Manusia, (Bogor: CV Pustaka Setia).

Syamsudin Aan, Munawar. 2013. Metode Riset Kuantitatif Komunikasi, (Yogyakarta: Pustaka Pelajar).

\section{Lainnya:}

Arini, Disti Utami. (2016). Persepsi Ibu Rumah Tangga Terhadap Serial Drama Televisi Elif di SCTV Riset Audiens di Kelurahan Caile Kabupaten Bulukumba. Program Studi S1 Komunikasi Universitas Hasanuddin

Rusmana, Fitrah Lelyani. (2017). Tanggapan dan Ketertarikan Ibu Rumah Tangga Terhadap "Sinema Pintu Taubat" di Indosiar (Studi Terhadap Ibu-ibu Rumah Tangga di Desa Baruga, Luwu Timur). Program Studi S1 Komunikasi Universitas Fajar.

Rismayanti. (2011). Tanggapan Siswa SMAN 17 Makassar Terhadap Tayangan Komedi Opera Van Java (OVJ TRANS7). Program Studi S1 Komunikasi Universitas Fajar.

\section{Internet:}

(https://id.m.wikipedia.org/wiki/RCTI)

(www.duniatv.net )

(http://id.m.wikipedia.org/wiki/Kesultanan_Tidore)

(https://id.m.wikipedia.org/wiki/Dunia terbalik 